DOI: $10.14720 /$ aas.2016.107.1.17

Agrovoc descriptors: allelopathy; weeds; cultural weed control; medicago sativa; nitrogen fertilizers; sorghum, tobacco; nicotiana tabacum

Agris category code: H60, f04, f62

\title{
Effects of different nitrogen levels on phytotoxicity of some allelopathic crops
}

\author{
Y. NOROUZI ${ }^{1}$, G. R. MOHAMMADI ${ }^{1} *$ and I. NOSRATTI ${ }^{1}$
}

Received April 28, 2015; accepted February 16, 2016.

Delo je prispelo 28. aprila 2015, sprejeto 16. februarja 2016.

\begin{abstract}
Intensive usage of herbicides can result in the serious negative impacts on environment. Allelopathy by reducing seed germination and early seedling growth can play a fundamental role in suppressing weeds in crop fields. The effectiveness of allelochemicals is governed by different factors such as soil nutrient status, $\mathrm{pH}$ and microorganisms. Outdoor pot experiments were conducted at the Faculty of Agriculture and Natural Resources of Razi University, Kermanshah, Iran, in 2013, to evaluate the effects of different levels of $\mathrm{N}$ fertilizer $\left(0,150,300 \mathrm{~kg} \mathrm{ha}^{-1}\right)$ on the suppressing effects of alfalfa (Medicago sativa L.), sorghum (Sorghum bicolor L.), and tobacco (Nicotiana tabacum L.) plant materials on emergence and growth parameters of some weed species including Johnson grass (Sorghum halepense (L.) Pers.), barnyard grass (Echinochloa crus-galli (L.) Beauv.) and redroot pigweed (Amaranthus retroflexus L.). Results indicated that adding plant materials of tobacco, sorghum, and alfalfa substantially reduced seed germination and early growth of the tested weeds. However, the weed species responded differently to the presence of the allelopathic plant materials. The use of $\mathrm{N}$ fertilizer had significant effects on the inhibitory potentials of the allelopathic plants. However, we didn't find consistent trends regarding the responses of the allelopathic crops to elevated $\mathrm{N}$ fertilizer levels in related to the traits under study.
\end{abstract}

Key words: alfalfa, allelopathy, nitrogen, sorghum, tobacco, weeds

\section{IZVLEČEK \\ UČINKI RAZLIČNIH ODMERKOV DUŠIKA NA FITOTOKSIČNOST NEKATERIH ALELOPATIČNIH POLJŠČIN}

Intenzivna raba herbicidov ima lahko resne negativne vplive na okolje. $\mathrm{Z}$ zmanjševanjem kalitve in začetne rasti lahko igra alelopatija pomembno vlogo pri zatiranju plevelov. Na učinkovitost alelokemikalij vplivajo številni dejavniki kot so količina hranil $\mathrm{v}$ tleh, $\mathrm{pH}$ in mikroorganizmi. Na Faculty of Agriculture and Natural Resources of Razi University, Kermanshah, Iran, je bil v letu 2013 izveden lončni poskus na prostem, $\mathrm{z}$ namenom ovrednotenja različnih odmerkov $\mathrm{N}$ gnojil $\left(0,150,300 \mathrm{~kg} \mathrm{ha}^{-1}\right)$ na zaviralni učinek lucerne (Medicago sativa L.), navadnega sirka (Sorghum bicolor L.), in navadnega tobaka (Nicotiana tabacum L.). Po dodatku zmletih nadzemnih delov teh poljščin so spremljali vznik in rastne parameter treh plevelov, divjega sirka (Sorghum halepense (L.) Pers.), navadne kostrebe (Echinochloa crusgalli (L.) Beauv.) in navadnega ščira (Amaranthus retroflexus L.). Rezultati so pokazali, da je dodatek navadnega tobaka, navadnega sirka in lucerne znatno zmanšal kalitev in zgodnjo rast testiranih treh plevelov. Testirani pleveli so se različno odzvali na dodatke alelopatskih rastlinskih ostankov. Uporaba dušičnih gnojil je imela značilen učinek na inhibitorni potencial alelopatskih rastlin, vendar niso uspeli ugotoviti konsistentnega trenda med odzivi plevelov na dodatke alelopatskih rastlin in povečanimi odmerki dušičnih gnojil.

Ključne besede: lucerna, navadni sirek, navadni tobak, alelopatija, dušikova gnojila, pleveli

\section{INTRODUCTION}

Based on the oldest definition by Molisch (1937), the adverse effect of one plant species on neighboring plants via releasing of toxic chemicals is called as allelopathy. Several plant species have shown allelopathic capability (Macias et al., 2004). Alfalfa (Medicago sativa L.), sorghum (Sorghum

\footnotetext{
1 Department of crop production and breeding, Faculty of Agriculture and Natural Resources, Razi University, Kermanshah, Iran

* Corresponding author: E-mail addresses: mohammadi114@yahoo.com
} 
bicolor L.) and tobacco (Nicotiana tabacum L.) are extensively cultivated across the Iranian farmlands which have shown allelopathic potential in Petri dish trials (Nielsen et al., 1960; Klein and Miller, 1980; Jensen et al., 1981; Tesar, 1986; Hedge and Miller, 1990; Sène et al., 2000; Chon and Kim, 2004; Rehman et al., 2010). Alfalfa plant tissues and their aqueous extracts can inhibit the germination and seedling growth of a number weed species (Singh et al., 2003). Florentine et al. (2005) reported that the aqueous extract of tobacco shoots have inhibitory effects on growth and germination of some crops. According to Singh et al. (2003) all parts of sorghum release phytoinhibitors reducing the growth of grass and broadleaf weed species. Annually thousand tons of residues of these crops are incorporated into the agricultural soils which can be used as a useful alternative tool for weed control. By integrating of allelopathic plants to a weed management program, the need for herbicide to control weeds would diminish substantially (Dilipkumar et al, 2012).

In addition to reduce the cost of weed management, environment would not be affected by artificial herbicides. Unlike artificial herbicides, the use of allelopathy for weed suppression in agroecosystems is a complicated practice. A broad range of different factors can influence the allelopathic activity of allelochemicals, including soil and climatic conditions (Ponder et al., 1985; Blum, 1998; Kobayashi, 2004; Inderjit, 2005). Nevertheless, there is not a lot of works describing the inhibitory effects of allelopathic plant materials as influenced by soil factors. Physicochemical properties of soil as well as the soil organic matter, fertility and organisms have great impacts on adsorption, desorption, transport and the metabolism of allelochemicals in soil (Inderjit, 2001). Although, it has been demonstrated that seed germination of several weed species is stimulated by nitrogenous compounds like nitrate and ammonium (Adkins and Adkins 1994; Hartmann et al. 1997; Teasdale and Pillai, 2005) but the effects of this nutrient element on the potential of allelochemicals to reduce seed germination and growth of weeds under soil environment is not well known. Although, it has been well documented that allelopathy affects several biological processes in nitrogen cycle (Jobidon and Thibault, 1982; Weston and Putnam, 1985; Alsaadawi et al., 1986; Alsaadawi, 1988; Rice, 1992; Zwain et al, 1998). The purpose of this study was to evaluate the effects of different levels of nitrogen fertilizer on the inhibitory potentials of alfalfa, sorghum and tobacco on seed germination and early seedling growth of barnyard grass (Echinochloa crus-galli (L.) Beauv.), Johnson grass (Sorghum halepense (L.) Pers.) and redroot pigweed (Amaranthus retroflexus L.), some dominant weed species in many regions of Iran.

\section{MATERIALS AND METHODS}

This outdoor pot experiment was conducted at the Faculty of Agriculture and Natural Resources of Razi University, Kermanshah $\left(34^{\circ} 18^{\prime} 51^{\prime \prime} \mathrm{N}\right.$, $4^{\circ} 03^{\prime} 54^{\prime \prime} \mathrm{E}$; elevation $1350 \mathrm{~m}$.), Iran during June to September of 2013. During the experiments, the mean temperature and relative humidity were $26.6^{\circ} \mathrm{C}$ and $12.8 \%$, respectively. Ten seeds of Johnson grass, redroot pigweed and barnyard grass were sown in plastic pots with a diameter of 13 and a height of $19 \mathrm{~cm}$ containing $1.9 \mathrm{~kg}$ of field soil. Each pot was treated with powdered plant tissues including shoot and root of alfalfa, tobacco or sorghum. The allelopathic plant materials were prepared from the plants grown in the Research Field of Razi University and harvested just before flowering stage. After harvesting, the allelopathic plants were air-dried in the shade and then ground.
The amount of powdered allelopathic plant tissues added to each pot was $16 \mathrm{~g}$. This amount equalled with $11400 \mathrm{~kg} \mathrm{ha}^{-1}$ and was the lowest effective concentration which was determined according to the results of our preliminary experiments (data not shown). Three levels of $\mathrm{N}$ fertilizer, 0,2 and $4 \mathrm{~g}$ (as urea) were added to the pots which equalled with 0,150 and $300 \mathrm{~kg} \mathrm{ha}^{-1}$, respectively. Three non-treated pots were also included as control. The trial was conducted as a factorial based on a completely randomized design with three replications and was repeated twice.

The number of emerged seedlings in each pot was recorded daily up to the seedling establishment was stabilized. Then the mean emergence rate 
(MER) was calculated according to the following equation (Ellis and Roberts 1980):

$\mathrm{MER}=\sum \mathrm{n} / \sum \mathrm{Dn}$

where $n$ is the number of seedling emerged on day $\mathrm{D}$ and $D$ is the number of days from the start of experiment.

Moreover, seedling emergence percentage was determined when the seedling establishment was stabilized.

Then weeds were thinned to five plants in each pot and were irrigated as needed throughout the experiment. Two weeks after weed emergence, leaf chlorophyll content (based on SPAD value) was measured on three randomly selected leaves of each plant by using a SPAD meter model (SPAD502, Minolta, Japan), weekly. Other traits of the weed species including plant height, the number of tillers per plant, root length, the number of leaf per plant and shoot and root dry mass were determined at 35 days after the start of experiment. To determine shoot and root dry mass, these plant organs were dried at $70{ }^{\circ} \mathrm{C}$ for $48 \mathrm{~h}$ and then their mass was recorded. Obtained data were subjected to ANOVA and means were separated using Fisher's Protected LSD test at the 0.05 level of probability by using SAS software (SAS Institute 2003).

\section{RESULTS}

\subsection{Barnyard grass}

The results showed that alfalfa had the greatest reducing effect on barnyard grass seedling emergence under all three nitrogen levels with a positive response to increasing nitrogen fertilizer (Table 1), as the lowest seedling emergence caused by alfalfa occurred at the highest $\mathrm{N}$ level. Nitrogen application in a rate of $150 \mathrm{~kg} \mathrm{ha}^{-1}$ decreased barnyard grass seedling emergence under tobacco and sorghum treatments but their reducing effects diminished when $\mathrm{N}$ level increased from 150 to $300 \mathrm{~kg} \mathrm{ha}^{-1}$ (Table 1). The lowest barnyard grass root dry masst was recorded for sorghum treatment when $\mathrm{N}$ fertilizer was not applied (Table 1). In general, root dry mass responded positively to the increasing $\mathrm{N}$ level under tobacco and sorghum treatments, although this trait was not significantly influenced by $\mathrm{N}$ application when soil was treated by alfalfa plant material (Table 1 ).

Table 1: Barnyard grass emergence and root dry mass as influenced by different nitrogen levels and allelopathic treatments

\begin{tabular}{cccc}
\hline $\begin{array}{c}\text { Allelopathic } \\
\text { treatment }\end{array}$ & $\begin{array}{c}\text { Nitrogen level }(\mathrm{kg} \\
\left.\mathrm{h}^{-1}\right)\end{array}$ & $\begin{array}{c}\text { Seedling } \\
\text { emergence }(\%)\end{array}$ & $\begin{array}{c}\text { Root dry masst } \\
(\mathrm{g} \mathrm{plant})\end{array}$ \\
\hline Control & & $83.33^{\mathrm{ab}}( \pm 1.923)$ & $4.12^{\mathrm{a}}( \pm 0.092)$ \\
\hline \multirow{2}{*}{ Tobacco } & 150 & $70.00^{\mathrm{bc}}( \pm 0.000)$ & $0.71^{\mathrm{d}}( \pm 0.064)$ \\
& 300 & $83.33^{\mathrm{cd}}( \pm 3.333)$ & $1.87^{\mathrm{b}}( \pm 0.132)$ \\
& 0 & $46.66^{\mathrm{ef}}( \pm 3.333)$ & $1.07^{\mathrm{cd}}( \pm 0.328)$ \\
& 150 & $36.66^{\mathrm{fg}}( \pm 3.333)$ & $1.07^{\mathrm{cd}}( \pm 0.302)$ \\
Alfalfa & 300 & $30.00^{\mathrm{g}}( \pm 5.774)$ & $1.06^{\mathrm{cd}}(0.094)$ \\
\hline & 0 & $53.33^{\mathrm{de}}( \pm 8.819)$ & $0.89^{\mathrm{cd}}( \pm 0.103)$ \\
& 150 & $43.33^{\mathrm{efg}}( \pm 3.333)$ & $0.96 \mathrm{~cd}( \pm 0.269)$ \\
Sorghum & 300 & $46.66^{\mathrm{ef}}( \pm 6.667)$ & $1.29^{\mathrm{c}}( \pm 0.142)$ \\
\hline LSD $_{(0.05)}$ & & 16.13 & 0.53
\end{tabular}

Means ( \pm SE) within a column followed by the same letter are not significantly different at the 0.05 level of probability (LSD test). 


\subsection{Redroot pigweed}

Redroot pigweed plant height was significantly increased in response to increasing $\mathrm{N}$ level under alfalfa and sorghum treatments, as the highest plant heights were recorded in the highest level of $\mathrm{N}$ fertilizer (Table 2). However, in the soil treated by tobacco plant material, increasing $\mathrm{N}$ level from 150 to $300 \mathrm{~kg} \mathrm{ha}^{-1}$ led to a notable reduction in redroot pigweed plant height (Table 2). Under zero level of $\mathrm{N}$ in the soil treated by sorghum plant material, the greatest reduction in red root pigweed plant height was observed. In general, in the pots containing sorghum plant material, with increasing $\mathrm{N}$ concentration the inhibitory effect was reduced (Table 2). In the pots treated by alfalfa, increasing $\mathrm{N}$ level from 150 to $300 \mathrm{~kg} \mathrm{ha}^{-1}$ increased redroot pigweed height compared to control. For tobacco plant material, with increasing $\mathrm{N}$ level from 150 to $300 \mathrm{~kg} \mathrm{ha}^{-1}$, redroot pigweed height decreased significantly. Addition of $300 \mathrm{~kg} \mathrm{ha}^{-1}$ of $\mathrm{N}$ fertilizer to the soil treated with sorghum plant material produced the lowest number of leaves when compared with control (Table 2). As a general rule, in double-dose of $\mathrm{N}$ fertilizer, the reducing effects of alfalfa and tobacco on the number of redroot pigweed leaf were increased. The lowest values of root dry mass when compared to control were observed at the zero level of $\mathrm{N}$ under all allelopathic treatments. In the presence of tobacco plant material, with increasing $\mathrm{N}$ fertilizer, root dry mass was increased while for sorghum and alfalfa decreasing trends were observed (Table 2). The lowest redroot pigweed root length occurred in the pots treated by alfalfa plant materials under zero level of $\mathrm{N}$ fertilizer (Table 2). Increasing $\mathrm{N}$ level decreased the inhibitory effects of all allelopathic plant materials on root length, although in the soil treated by tobacco, redroot pigweed root length was significantly higher under zero level of $\mathrm{N}$ than that in the level of $150 \mathrm{~kg} \mathrm{ha}^{-1}$ (Table 2). Nitrogen application in the soil treated by sorghum plant material led to the highest reduction in redroot pigweed emergence (Table 2). For tobacco treatment, the use of $\mathrm{N}$ fertilizer also significantly reduced seedling emergence compared to control, although there was no significant difference between the low and the high fertilizer levels in terms of their effects on this trait (Table 2). Alfalfa responded inversely to $\mathrm{N}$ application as its inhibitory effect decreased with increasing $\mathrm{N}$ fertilizer level (Table 2).

Table 2: Redroot pigweed emergence and plant traits as influenced by different nitrogen levels and allelopathic treatments

\begin{tabular}{ccccccc}
\hline $\begin{array}{c}\text { Allelopathic } \\
\text { treatment }\end{array}$ & $\begin{array}{c}\text { Nitrogen } \\
\text { level } \\
\left(\mathrm{kg} \mathrm{ha}^{-1}\right)\end{array}$ & Plant height $(\mathrm{cm}$ & $\begin{array}{c}\text { Leaf number } \\
\left(\text { no plant }{ }^{-1}\right)\end{array}$ & $\begin{array}{c}\text { Root dry mass }(\mathrm{g} \\
\text { plant })^{-1}\end{array}$ & $\begin{array}{c}\text { Root length } \\
(\mathrm{cm})\end{array}$ & $\begin{array}{c}\text { Seedling } \\
\text { emergence }(\%)\end{array}$ \\
\hline Control & & $11.00^{\mathrm{bc}}( \pm 0.577)$ & $72.33^{\mathrm{a}}( \pm 1.345)$ & $0.78^{\mathrm{bcd}}( \pm 0.046)$ & $25.16^{\mathrm{bc}}( \pm 1.155)$ & $73.33^{\mathrm{a}}( \pm 1.923)$ \\
\hline \multirow{2}{*}{ Tobacco } & 150 & $10.53^{\mathrm{cd}}( \pm 1.048)$ & $27.00^{\mathrm{ef}}( \pm 3.512)$ & $0.32^{\mathrm{e}}( \pm 0.078)$ & $20.66^{\mathrm{de}}( \pm 0.028)$ & $60.00^{\mathrm{b}}( \pm 0.000)$ \\
& 300 & $9.80^{\mathrm{cd}}( \pm 0.709)$ & $41.33^{\mathrm{cd}}( \pm 2.028)$ & $0.55^{\mathrm{cde}}( \pm 0.068)$ & $22.00^{\mathrm{cd}}( \pm 2.517)$ & $36.36^{\mathrm{cd}}( \pm 3.333)$ \\
\hline \multirow{2}{*}{ Alfalfa } & 0 & $10.50^{\mathrm{cd}}( \pm 0.764)$ & $47.33^{\mathrm{bc}}( \pm 3.180)$ & $0.34^{\mathrm{e}}( \pm 0.037)$ & $9.33^{\mathrm{f}}( \pm 0.882)$ & $23.33^{\mathrm{ef}}( \pm 3.333)$ \\
& 150 & $9.83^{\mathrm{cd}}( \pm 1.202)$ & $52.00^{\mathrm{b}}( \pm 4.041)$ & $1.24^{\mathrm{a}}( \pm 0.036)$ & $11.33^{\mathrm{f}}( \pm 2.892)$ & $30.00^{\mathrm{de}}( \pm 0.000)$ \\
& 300 & $14.20^{\mathrm{a}}( \pm 0.473)$ & $39.33^{\mathrm{d}}( \pm 2.186)$ & $0.94^{\mathrm{ab}}( \pm 0.055)$ & $23.33^{\mathrm{cd}}( \pm 0.667)$ & $53.33^{\mathrm{b}}( \pm 3.333)$ \\
\hline Sorghum & 0 & $7.86^{\mathrm{d}}( \pm 0.948)$ & $39.33^{\mathrm{d}}( \pm 2.333)$ & $0.21^{\mathrm{e}}( \pm 0.006)$ & $17.00^{\mathrm{e}}( \pm 0.577)$ & $40.00^{\mathrm{c}}( \pm 0.000)$ \\
& 150 & $10.10^{\mathrm{cd}}( \pm 0.379)$ & $30.66^{\mathrm{e}}( \pm 1.202)$ & $0.92^{\mathrm{abc}}( \pm 0.025)$ & $29.00^{\mathrm{ab}}( \pm 0.577)$ & $10.00^{\mathrm{g}}( \pm 0.000)$ \\
& 300 & $13.56^{\mathrm{ab}}( \pm 1.260)$ & $22.33^{\mathrm{f}}( \pm 1.453)$ & $0.41^{\mathrm{de}}( \pm 0.024)$ & $31.00^{\mathrm{a}}( \pm 1.528)$ & $20.00^{\mathrm{f}}( \pm 5.774)$ \\
\hline LSD $(0.05)$ & & 3.00 & 6.72 & 0.37 & 4.33 & 8.88
\end{tabular}

Means ( \pm SE) within a column followed by the same letter are not significantly different at the 0.05 level of probability (LSD test). 


\subsection{Johnson grass}

$\mathrm{N}$ fertilizer at the level of $150 \mathrm{~kg} \mathrm{ha}^{-1}$ and in the presence of alfalfa plant material had the greatest inhibitory effect on Johnson grass seedling emergence (a $81 \%$ reduction compared to control) (Table 3). Increasing $\mathrm{N}$ level from 0 to $150 \mathrm{~kg} \mathrm{ha}^{-1}$ in the soil treated by tobacco or alfalfa decreased Johnson grass emergence but the inhibitory effects of these allelopathic crops were significantly reduced at the highest level of $\mathrm{N}$ fertilizer $\left(300 \mathrm{~kg} \mathrm{ha}^{-1}\right)$. However, increasing $\mathrm{N}$ level from 0 to $300 \mathrm{~kg} \mathrm{ha}{ }^{-1}$ consistently enhanced sorghum reducing effect on the weed seedling emergence (Table 3). Adding the $300 \mathrm{~kg} \mathrm{ha}^{-1}$ of $\mathrm{N}$ fertilizer in the presence of sorghum plant material had the highest inhibitory effect on the number of leaf per plant followed by tobacco and alfalfa, respectively (Table 3). Johnson grass leaf number was not significantly influenced by different $\mathrm{N}$ fertilizer levels in the soil treated by tobacco plant material.
However, in the presence of sorghum plant material, this trait showed a significant decreasing response to increasing $\mathrm{N}$ level from 150 to $300 \mathrm{~kg}$ $\mathrm{ha}^{-1}$ (Table 3 ). In the soil treated by alfalfa, the highest and the lowest reductions in the number of leaf occurred at the 0 and $150 \mathrm{~kg} \mathrm{ha}^{-1}$ levels of $\mathrm{N}$ fertilizer, respectively (Table 3 ). For all three allelopathic plants, Johnson grass shoot dry mass was decreased in response to increasing soil nitrogen level (Table 3). However, the highest reductions occurred in the soil treated with sorghum plant material, as the lowest shoot dry mass was observed when pots treated by this allelopathic plant and received the highest level of $\mathrm{N}$ fertilizer (Table 3). Although, increasing $\mathrm{N}$ level in the soil containing tobacco plant material increased its reducing effect on shoot dry mass of Johnson grass but this was not significant from a statistical viewpoint (Table 3).

Table 3: Johnson grass emergence and plant traits as influenced by different nitrogen levels and allelopathic treatments

\begin{tabular}{|c|c|c|c|c|}
\hline $\begin{array}{l}\text { Allelopathic } \\
\text { treatment }\end{array}$ & $\begin{array}{c}\text { Nitrogen level } \\
\qquad\left(\mathrm{kg} \mathrm{ha}^{-1}\right)\end{array}$ & $\begin{array}{c}\text { Seedling } \\
\text { emergence }(\%)\end{array}$ & $\begin{array}{l}\text { Leaf number } \\
\text { (no plant }^{-1} \text { ) }\end{array}$ & $\begin{array}{l}\text { Shoot dry mass } \\
\left.\text { (g plant }^{-1}\right)\end{array}$ \\
\hline Control & & $70.00^{\mathrm{a}}( \pm 1.732)$ & $33.66^{\mathrm{a}}( \pm 1.555)$ & $2.53^{\mathrm{a}}( \pm 0.289)$ \\
\hline \multirow{3}{*}{ Tobacco } & 0 & $26.66^{\mathrm{bcd}}( \pm 3.333)$ & $16.00^{\mathrm{ef}}( \pm 1.000)$ & $0.86^{\mathrm{cd}}( \pm 0.181)$ \\
\hline & 150 & $23.33^{\text {bcde }}( \pm 3.333)$ & $17.33^{\mathrm{de}}( \pm 1.764)$ & $0.76^{\mathrm{de}}( \pm 0.019)$ \\
\hline & 300 & $33.33^{\mathrm{b}}( \pm 6.667)$ & $16.66^{\mathrm{de}}( \pm 1.333)$ & $0.84^{\mathrm{d}}( \pm 0.080)$ \\
\hline \multirow{3}{*}{ Alfalfa } & 0 & $20.00^{\mathrm{cde}}( \pm 5.774)$ & $19.66^{\mathrm{cd}}( \pm 1.453)$ & $1.31^{\mathrm{b}}( \pm 0.009)$ \\
\hline & 150 & $13.00^{\mathrm{e}}( \pm 3.333)$ & $24.33^{\mathrm{b}}( \pm 1.202)$ & $1.23^{\mathrm{bc}}( \pm 0.066)$ \\
\hline & 300 & $33.33^{\mathrm{b}}( \pm 3.333)$ & $21.66^{\mathrm{bc}}( \pm 1.764)$ & $0.69^{\mathrm{de}}( \pm 0.104)$ \\
\hline \multirow{3}{*}{ Sorghum } & 0 & $30.00^{\mathrm{bc}}( \pm 0.000)$ & $17.66^{\mathrm{de}}( \pm 0.882)$ & $1.34^{\mathrm{b}}( \pm 0.091)$ \\
\hline & 150 & $20.00^{\mathrm{cde}}( \pm 5.774)$ & $16.66^{\mathrm{de}}( \pm 0.882)$ & $0.79^{\mathrm{d}}( \pm 0.102)$ \\
\hline & 300 & $16.66^{\mathrm{de}}( \pm 3.333)$ & $13.00^{\mathrm{f}}( \pm 0.577)$ & $0.40^{\mathrm{e}}( \pm 0.009)$ \\
\hline $\operatorname{LSD}_{(0.05)}$ & & 10.88 & 3.64 & 0.37 \\
\hline
\end{tabular}

Means $( \pm$ SE) within a column followed by the same letter are not significantly different at the 0.05 level of probability (LSD test).

\section{DISCUSSION}

As it is evident from the results, weed species and the traits under study responded variously to the presence of different allelopathic plant materials in soil. Different susceptibility of weed species to allelochemicals from several plant species has been reported, previously (Batish et al., 2002;
Kobayashi, 2004). Differences in the responses of weed species to allelochemicals might be due to some weed characteristics including seed size (Liebman and Sundberg, 2006). The use of N fertilizer had significant effect on the suppressing ability of allelopathic plant materials on the 
examined weed species. However, the weed species and the traits under study responded to different $\mathrm{N}$ fertilizer levels, inconsistently. According to Inderjit (2001) soil physical, chemical (e.g. inorganic ions) and biological properties can influence the effects of allelochemicals. Other workers have also demonstrated that soil properties can greatly affect allelopathy phenomena in various ways (Tongma et al., 2001; Hiradate et al., 2010). Different effects of $\mathrm{N}$ is probably due to its different influences on the microbes which decompose plant materials, as each one has its own specific microorganism capable of degrading its plant material (Kumar et al., 1993; Schmidt and Lipson, 2004; Inderjit, 2005; Xuan et al., 2005). The $\mathrm{C} / \mathrm{N}$ ratio of the allelopathic crop materials is another important factor which can influence the rate of the release of allelochemicals into the soil and consequently their inhibitory effects on germination and seedling growth of weeds. A crop such as alfalfa with a low $\mathrm{C} / \mathrm{N}$ ratio may be decomposed by soil microorganisms rapidly and releases its phythotoxins into the soil in a higher rate. Therefore, it can be expected that the crops with higher $\mathrm{C} / \mathrm{N}$ ratios such as tobacco and sorghum show more positive responses to the elevated soil nitrogen concentration resulted from $\mathrm{N}$ fertilizer application when compared with alfalfa. However, in our study there were no consistent trends regarding the responses of the allelopathic plant materials to different $\mathrm{N}$ fertilizer levels in related to the traits under study. Increasing the emergence and seedling growth of some weeds in the allelopathic plant-treated soils in response to $\mathrm{N}$ application can be attributed to the stimulatory effects of this element on germination of some weed species (Adkins et al., 2002). In general, adding plant materials of tobacco, sorghum, and alfalfa substantially reduced seed germination and early growth of the three weed species under study. These weed species can seriously reduce crop production and their chemical control is somehow difficult and costly (Holm et al., 1991; Zimdahl, 2007). The most practical aspect of allelopathy as a tool to control weeds is its suppressing effect on seed germination of these unwanted plants. Because, it seems that allelochemicals may have lower inhibitory effects on weeds at the later stages of their life cycle.

\section{CONCLUSION}

In our study, the emergence of all weed species was notably reduced in the soils treated by the allelopathic plant materials. This reveals that allelopathy may be proposed as a promising tool in an integrated weed management (IWM) program and allelopathic plants can be included in crop rotations to reduce weed infestation in subsequent crops. However, their negative effects on germination and growth of subsequent crops should be considered, precisely. $\mathrm{N}$ fertilizer may have different effects on the weed suppressing ability of allelopathic crops in related to several factors including the nature of crop and weed species and soil physical, chemical and biological conditions such as microorganism communities. Certainly, further studies are needed to investigate these factors.

\section{REFERENCES}

Adkins S.W. and Adkins A.L. 1994. Effect of potassium nitrate and ethephon on fate of wild oat (Avena fatua) seeds in soil. Weed Science 42: 353-357.

Adkins S.W., Bellairs S.M. and Loch D.S. 2002. Seed dormancy mechanisms in warm season grass species. Euphytica 126: 13-20. DOI: 10.1023/A:1019623706427

Alsaadawi, I.S. 1988. Biological suppression of nitrification by selected cultivars of Helianthus annuus L. Journal of Chemical Ecology 14: 722732. DOI: $10.1007 /$ BF01018768

Alsaadawi, I.S., Al-Uqaili, J.K., Al-Rubeaa, A.J. and Al-Hadithy, S.M. 1986. Allelopathic suppression of weeds and nitrification by selected cultivars of Sorghum bicolor L. (Moench). Journal of Chemical Ecology 12: 209-219. DOI: 10.1007/BF01045604

Batish, D.R., Singh H., Jasvir P., Andher P.K., Arora, V. and Kohli R.K. 2002. Phytotoxic effect of Parthenium residues on the selected soil properties 
and growth of chickpea and radish. Weed Biology and Management 2: 73-78. DOI: $10.1046 /$ j.14456664.2002.00050.x

Blum U. 1998. Effects of microbial utilization of phenolic acids and their phenolic acid breakdown products on allelopathic interactions. Journal of Chemical Ecology 24: 685-708. DOI: 10.1023/A:1022394203540

Chon, S.U. and Kim Y.M. 2004. Herbicidal potential and quantification of suspected allelochemicals from four grass crop extracts. J. Agron. Crop Science 190:145-150. DOI: $10.1111 / \mathrm{j} .1439-$ 037X.2004.00088.X

Dilipkumar, M., Adzemi, M.A. and Chuah T.S. 2012. Effects of soil types on phytotoxic activity of pretilachlor in combination with sunflower leaf extracts on barnyard grass (Echinochloa crus-galli). Weed Science 60:126-132. DOI: 10.1614/WS-D11-00075.1

Ellis, R.H. and Roberts, E.H. 1980. Towards Rational Basis for Testing Seed Quality, pp. 605-635 in Hebblethwaite, P.D. (Ed.) Seed Production. Butterworths, London, UK.

Florentine S.K., Westbrooke M.E. and Graham R. 2005 Invasion of the noxious weed Nicotiana glauca after an Orobanche crenata in legumes. Crop Protection 26: 1166- 1173.

Hartmann K., Kroosz C. and Mollwo A. 1997. Phytochrome-mediated photocontrol of the germination of the Scentless Mayweed, Matricaria inodora L., and its sensitization by nitrate and temperature. Journal Photoch Photobiol Biology 40: 240-252. DOI: 10.1016/S1011-1344(97)00064$\mathrm{X}$

Hedge R.S. and Miller D.A. 1990. Allelopathy and autotoxicity in alfalfa: Characterization and effects of preceding crops and residue incorporation. Crop Science 30: 1255-1259. DOI: 10.2135/cropsci1990.0011183X003000060020x

Hiradate, S., Ohse, K., Furubayashi, A. and Fujii, Y. 2010. Quantitative evaluation of allelopathic potentials in soils: Total activity approach. Weed Science 58: 258-264. DOI: 10.1614/WS-D-0900085.1

Holm, L.G., Plucknett L. and Herberger J.P. 1991. The world's worst weeds, distribution and biology krieger publishing company. Malabor. Florida.

Inderjit, 2001. Soil environment effects on allelochemical activity. Agronomy Journal 93: 7984.
Inderjit, 2005. Soil microorganisms: An important determinant of allelopathic activity. Plant and Soil 274: 227-236.

Jensen E.H., Hartman B.J., Lundin F., Knapp S. and Brookerd B. 1981. The autotoxicity of alfalfa. In: Nevada Agricultural Experimental Report, Report 144. Nevada Agriculture Experiment Report, Nevada Cooperative Extension Publication, Reno,Nevada.

Jobidon, R. and Thibault, J.R. 1982. Growth inhibition of nodulated and un-nodulated Alnus crispa seedlings by populous balsmifera. American Journal of Botany 69: 1213-1223. DOI: $10.2307 / 2442745$

Klein R.R. and Miller D.A. 1980. Allelopathy and its role in agriculture. Communications in Soil Sciences and Plant Analysis 11:43-56. DOI: 10.1080/00103628009367014

Kobayashi, K. 2004. Factors affecting phytotoxic activity of allelochemicals in soil. Weed Biology and Management 4: 1-7. DOI: $10.1111 /$ j.14456664.2003.00112.x

Kumar, P., Gagliardo, R. and Chilton, W. 1993. Soil transformation of wheat and corn metabolites mboa and DIMBOA into aminophenoxazinones. Journal of Chemical Ecology 19: 2453-2461. DOI: 10.1007/BF00980682

Liebman, M. and Sundberg D.N. 2006. Seed mass affects the susceptibility of weed and crop species to phytotoxins extracted from red clover shoots. Weed Science 54:340-345.

Macias F.A., Galindo J.C.G., Molinillo J.M.G. and Cutler H.G. 2004. Allelopathy: Chemistry and mode of action of allelochemicals. CRC Press, Boca Raton, Florida, 372 pp.

Nielsen K.F.,Cuddy T. and Woods W. 1960. The influence of the extracts of some crops and soil residues on germination and growth. Can. Journal Plant Science 40: 188-197. DOI: 10.4141/cjps60024

Ponder F. Jr and Tadros S.H. 1985. Juglone concentration in soil beneath black walnut interplanted with nitrogen-fixing species. Journal of Chemical Ecology 11: 937-942. DOI: 10.1007/BF01012079

Rehman, A., Cheema Z.A., Khaliq A., Arshad M. and Mohsan S. 2010. Application of sorghum, sunflower and rice water extract combinations helps in reducing herbicide dose for weed management in rice. Int. Journal Agriculture Biology 12: 901-906. 
Rice, E.L. 1992. Allelopathic effects on nitrogen cycle. In: Allelopathy: Basic and Applied Aspects. (Eds., S.J.H. Rizivi and V. Rizivi). Chapman and Hall Press, London. Chapter 4 pp. 31-58. DOI: 10.1007/978-94-011-2376-1_4

SAS Institute, 2003. SAS/STAT. User's Guide. Version 9.1. SAS Institute Inc., Cary, NC.

Schmidt, S.K. and Lipson, D.A. 2004 Microbial growth under the snow: Implications for nutrient and allelochemical availability in temperate soils. Plant and Soil 259: 1-7. DOI: 10.1023/B:PLSO.0000020933.32473.7e

Sène, M., Doré, T. and Pellissier, F. 2000. Effect of Phenolic Acids in Soil under and Between Rows of a Prior Sorghum (Sorghum bicolor) Crop on Germination, Emergence, and Seedling Growth of Peanut (Arachis hypogea). Journal of Chemical Ecology 26: 625-637. DOI: 10.1023/A:1005420020135

Singh H.P., Batish D.R. and Kohli R.K. 2003. Allelopathic interactions and allelochemicals: New possibilities for sustainable weed management. Critical Reviews in Plant Sciences 22: 239-311. DOI: $10.1080 / 713610858$

Teasdale J.R. and Pillai P. 2005. Contribution of ammonium to stimulation of smooth pigweed (Amaranthus hybridus L.) germination by extracts of hairy vetch (Vicia villosa Roth) residue. Weed Biology and Management 5: 19-25. DOI: 10.1111/j.1445-6664.2005.00155.x
Tesar, M.B. 1986. Re-establishing alfalfa after alfalfa without autotoxicity. In: Establishment of forage crops by conservation tillage methods: Pest control. Proceedings of the International Symposium, State College, PA 15-19.

Tongma, S., Kobayashi, K. and Usui, K. 2001. Allelopathic activity of Mexican sunflower [Tithonia diversifolia (Hemsl.) A. Gray] in soil under natural field conditions and different moisture conditions. Weed Biology and Management 1: 115-119. DOI: 10.1046/j.14456664.2001.00020.x

Weston, L.A. and Putnam, A.R. 1985. Inhibition of growth, nodulation and nitrogen fixation of legumes by quack grass (Agropyron repens). Crop Science 25: 561-566. DOI: 10.2135/cropsci1985.0011183X002500030031x

Xuan, T.D., Tawata, S., Khanh, T.D. and Chung, I.M. 2005. Decomposition of Allelopathic Plants in Soil. Journal of Agronomy and Crop Science 191: 162171.

DOI: 10.2135/cropsci1985.0011183X002500030031x

Zimdahl, R.L. 2007. Fundamentals of Weed Science. Academic Press. Colorado.

Zwain, K.H.Y., Alsaadawi, I.S. and Shahata, H.A. 1998. Effect of decomposing wheat residues on growth and biological nitrogen fixation of blue green algae. Allelopathy Journal 6: 13-20. 